IFN Working Paper No. 761, 2008

Productive and Destructive Entrepreneurship in a Political Economy Framework

Robin Douhan and Magnus Henrekson 


\title{
Productive and Destructive Entrepreneurship in a Political Economy Framework*
}

\author{
Robin Douhan $^{1,2}$ and Magnus Henrekson ${ }^{1}$
}

October 17, 2008

\begin{abstract}
Recent research has highlighted the role of institutions in channeling entrepreneurs into activities with positive or negative effects on overall productivity. Embedding central elements from these theories into a political economy framework reveals the bilateral causal relation between entrepreneurs and institutions. Core features of the entrepreneur force us to view its effects on institutions as more than mechanical general equilibrium adjustments. Three analytically separate channels of influence are isolated, analyzed and exemplified. Entrepreneurs influence formal economic institutions through direct involvement in politics, by using their entrepreneurial talent to wield de facto political power and by altering the effect of formal institutions. We propose a parsimonious framework that incorporates these effects as well as the role of institutions in channeling entrepreneurial talent. We use examples from modern history as a real-world context to illustrate our framework.
\end{abstract}

JEL Codes: L5; M13; O31; P14.

Keywords: Entrepreneurship; Innovation; Institutions; Regulation; Self-employment.

${ }^{1}$ Research Institute of Industrial
Economics (IFN)
Box 55665
SE-102 15 Stockholm
Phone: +46-8-665 4500
Fax: +46-8-665 4599
e-mail: $\underline{\text { magnus.henrekson@ifn.se }}$
$\quad$ robin.douhan@ifn.se

${ }^{1}$ Research Institute of Industrial

Box 55665

SE-102 15 Stockholm

Phone: +46-8-665 4500

Fax: +46-8-665 4599

robin.douhan@ifn.se

\author{
${ }^{2}$ Department of Economics \\ Uppsala University \\ Box 513 \\ SE-751 20 Uppsala \\ Phone: +46-8-665 4500 \\ Fax: +46-8-665 4599 \\ e-mail: robin.douhan@nek.uu.se
}

\footnotetext{
* This study was conducted within the Gustaf Douglas Research Program on Entrepreneurship at the Research Institute of Industrial Economics, Stockholm. We are grateful for useful comments and suggestions on an earlier version of this paper from Johan Almenberg, William Baumol, Niclas Berggren, Peter Boettke, Dan Johansson, Tino Sanandaji, and participants at the 2007 ISNIE Conference in Reykjavik.
} 


\section{Introduction}

Entrepreneurship is normally associated with profit-driven business activities. Still, political aspects of entrepreneurship have been dealt with in several strands of research, including the entrepreneurship/small-business literature and public choice. In this paper we develop a framework which unifies the political role of entrepreneurship with its traditional economic role. This amalgamation is a natural step given the emphasis on institutions in both the entrepreneurship/small-business literature and in public choice, and considering recent progress in the research on the political economy of growth.

It has been recognized for some time that institutions shape the actions of entrepreneurs (Parker, 2004, ch. 3). The seminal work by Baumol (1990) contributed to the literature by showing that not only the level, but also the type of entrepreneurship is determined by institutions. Individuals put their entrepreneurial talent to use in activities that are productive, unproductive or destructive. The relative returns and hence the allocation across these activities are determined by the institutional setup, i.e., the rules of the game.

An influential stream of research has built on the insight that abilities which can be used productively can also be used for rent extracting purposes (e.g., Murphy, Shleifer and Vishny, 1991, and Acemoglu, 1995). This literature typically stresses that the relative rates of return of different types of activities are determined by institutions. While recognizing the importance of institutions on entrepreneurship the relationship has typically been assumed to be (or at least analyzed as) unilateral, from institutions to entrepreneurship, while a potential reverse or bilateral causality has been ignored or ruled out. ${ }^{1}$

In this paper we embed entrepreneurship in a broader political economy context. By viewing institutions as endogenous to the system the analytical framework is changed. Entrepreneurship is allowed to have endogenous effects on institutions, i.e., the relationship between entrepreneurship and institutions can be bilateral. This possibility has been touched upon previously in the public choice school. Buchanan (1980, p. 14) noted: "Faced with a prospect of differentially unfavorable tax treatment by government, a person or a group may (1) engage in lobbying effort; (2) engage directly in politics to secure access to decision-

\footnotetext{
${ }^{1}$ Boettke and Coyne (2003) probably contain the strongest assertion that institutions are the ultimate cause of growth whereas entrepreneurship is merely a proximate cause, since its supply and direction is fully determined by the institutional setup.
} 
making power, and/or (3) make plans to shift into or out of the affected activity.” However, the subsequent public choice literature has rarely paid attention to this issue.

We generalize Buchanan's first and second point by stating that entrepreneurs affect institutions by: (i) direct political involvement and (ii) use entrepreneurial talent to strengthen their de facto political power. Moreover, we expand the list of causal channels by noting that entrepreneurs also partake in institutional change by (iii) altering the impact of formal institutions or by evading them. These mechanisms, together with the role of productive entrepreneurship, will be discussed in detail below.

It is important to stress that the effects entrepreneurs wield on institutions result from the talents embodied in entrepreneurial individuals; the effects are not mechanical general equilibrium responses that could be triggered by exogenous changes in other parts of the model. Hence, in a political economy context the entrepreneur must be explicitly modeled to identify and explore these mechanisms.

\section{Entrepreneurship Defined and Categorized}

\subsection{Entrepreneurial Talent}

We follow Baumol (1990) and Murphy et al. (1991) by defining an entrepreneur according to a set of talents. There is no consensus in the literature exploring the nature of these talents; some scholars emphasize cognitive abilities while others point to motivation (preferences). ${ }^{2}$ Entrepreneurial talent, in our model, makes an individual more perceptive and more dynamic, i.e., it includes both motivation and ability. The entrepreneur is apt to recognize opportunities and prone to take action in response. ${ }^{3}$ The kinds of opportunities we consider are either profitable business projects or opportunities to appropriate or earn rents.

\footnotetext{
${ }^{2}$ What are typical entrepreneurial properties? Two major research themes can be discerned: cognitive abilities and motivation. The prototypical entrepreneur is someone who is alert to opportunities. Cognitively, this amounts to structuring abundant information efficiently to make judgment feasible (Gaglio and Katz, 2001). It also involves a capacity to think imaginatively and in novel ways (Ward, 2004). As regards motives, the longest standing characterization of an entrepreneur is associated with the need to achieve and create (Weber, 2001[1905]; McClelland, 1961). Furthermore, an entrepreneur exhibits a willingness to take calculated (but not necessarily calculable) risks. Knight (1921) claims that the ability to cope with uncertainty is the main function of entrepreneurship. For a survey of the empirical evidence on these motivational aspects, see Rausch and Frese (2000). These properties are consistent with the historical accounts in Schumpeter (1934) and Kirzner (1973, 1992).

${ }^{3}$ Our definition is based on entrepreneurial talents. We note that this precludes any separation between successful and unsuccessful entrepreneurship. Implicitly, entrepreneurial talent is taken to increase both the
} 
In contrast to the abundance of scholarly uses of the entrepreneurship concept, we retain the strong association between entrepreneurship and the production system assumed in the small business literature (Wennekers and Thurik, 1999; Hébert and Link, 2006). ${ }^{4}$ Hence, the entrepreneur considered here is engaged in commercial business activities. We will discuss some instances where this entrepreneur enters the political sphere by indirectly wielding influence or even by becoming politically active. However, we abstract from political entrepreneurship in so far as it refers to the use of entrepreneurial talent by politicians who are disjoined from business activities.

Self-employment and the start-up of new firms are the prototypical forms of entrepreneurship both in reality and in the literature. However, our definition precludes many forms of selfemployment. Most importantly, self-employment due to a lack of other opportunities (often called necessity entrepreneurship) does not qualify as entrepreneurship.

For simplicity, we will treat the supply of entrepreneurially talented individuals as exogenous and focus on the relationship between entrepreneurial talent, institutions, and entrepreneurial activity. It is possible that the supply of entrepreneurially talented individuals varies over time, among other things depending on the institutional setup.

\subsection{Entrepreneurship - A Typology}

We follow Baumol (1990) in distinguishing among productive, unproductive and destructive entrepreneurship. ${ }^{5}$ In another dimension we add the possibility of either abiding by the rules of institutions or evading institutions. This creates a 3 x 2 matrix, where each entrepreneurial activity can be assigned to one of the six types.

\footnotetext{
likelihood of entrepreneurial venturing and the probability of success. Given the purpose of our analysis this is a simplification that comes at little cost of generality.

${ }^{4}$ In a survey of how entrepreneurship scholars define entrepreneurship Gartner (1990) found that almost one third regarded the profit motive as unimportant. Moreover, Gartner (2001, p. 34) concludes that: "There is no theory of entrepreneurship that can account for the diversity of topics that are currently pursued by entrepreneurship scholars."

${ }^{5}$ Sobel (2008) finds empirical support for Baumol’s theory.
} 
Baumol (1990) introduces his analysis as an extension of Schumpeter's (1934) theory of innovations as new combinations. Productive entrepreneurship is closely related to Schumpeter's (1934) discussion of new combinations. ${ }^{6}$

Unproductive and destructive entrepreneurship, on the other hand, entail some combination of rent-seeking technologies that enables the entrepreneur to appropriate rents from other agents. In this process, the social product may be unaffected, in the case of a simple transfer, or be lowered. In the terminology of the neoclassical theory of the firm, the distinction between the different types can be characterized as a shift inward (destructive) or outward (productive) of the production possibility frontier (Coyne and Leeson, 2004).

Given the definition of the entrepreneur it is untenable to assume that entrepreneurs passively respond to institutions. ${ }^{7}$ A second dimension of our typology therefore distinguishes behavior within the constraints of the institutions from evasion of these constraints. Evasive entrepreneurship is defined as an activity aimed at circumventing the institutional framework without an explicit violation. The distinction between abiding by and evading institutions is independent of the separation into different types of entrepreneurship.

These definitions are illustrated and exemplified in Figure 1. It should be noted that entrepreneurship always refers to activities and that the same person can be engaged in two or more kinds of activities at the same time.

\footnotetext{
${ }^{6}$ Productive entrepreneurship can entail: (i) introduction of a new good (or a new quality of a good); (ii) introduction of a new method of production; (iii) opening of a new market; (iv) conquest of a new source of supply of raw materials or semi-manufactured goods; (v) implementation of a new organizational form. One can summarize these points as new combinations of resources and technology on the market that create positive social value.

${ }^{7}$ Theories within the school of new institutional economics usually posit the entrepreneur as a key agent in institutional change. North (1990), for instance, holds that the entrepreneur acts on the fringe of a given institutional setup and is the agent that embodies dynamism and change in a setting where agents' behavior is otherwise determined by institutions. This is broadly consistent with the framework presented here.
} 


\begin{tabular}{c|c|c} 
& ABIDE & EVADE \\
\hline PRODUCTIVE & $\begin{array}{c}\text { Pursue a business opportunity } \\
\text { within prevailing institutions }\end{array}$ & $\begin{array}{c}\text { Sidestep regulation, or offer bribes, in } \\
\text { order to expand a profitable busines; } \\
\text { evade taxes on profits }\end{array}$ \\
\hline UNPRODUCTIVE & $\begin{array}{c}\text { Create contracts to overcome } \\
\text { institutional shortcomings; } \\
\text { lobbying; help others avoid } \\
\text { taxes }\end{array}$ & $\begin{array}{c}\text { Creation of a bureaucratic body where } \\
\text { rents are earned by selling licenses or } \\
\text { granting subsidized loans; help others } \\
\text { avoid/evade taxes }\end{array}$ \\
\hline DESTRUCTIVE & $\begin{array}{c}\text { Rogue states; rivalry between } \\
\text { warlords }\end{array}$ & $\begin{array}{c}\text { Illegal syndicates; the Mafia; } \\
\text { sophisticated fraud and economic } \\
\text { crimes }\end{array}$ \\
\hline
\end{tabular}

Figure 1. A Typology of Entrepreneurship and Some Illustrative Examples.

\section{The Entrepreneur in a Political Economy Context}

\subsection{The Politico-Economic Approach}

Equipped with the definitions and typology laid out in the previous sections we now introduce a complete politico-economic growth system. ${ }^{8}$ We adopt an extended version of the model in Acemoglu, Johnson and Robinson (2005). This model takes important steps towards a more rigorous general equilibrium analysis, while at the same time retaining a high level of parsimony.

Acemoglu et al. (2005) separate economic and political institutions. Institutions, more generally, shape human action and interaction, and are commonly referred to as "the rules of the game" that govern the conduct of economic activity and that result in "the social structure of payoffs" (Baumol, 1990). ${ }^{9}$ Economic institutions of particular importance for entrepreneurship include tax codes, social insurance systems, labor market legislation, competition policy, trade policies, capital market regulation, enforcement of contracts, and law and order (Hall and Jones, 1999). Constitutions are prime examples of political

\footnotetext{
${ }^{8}$ Bilateral causal effects between politics, institutions and economic performance have held a long standing interest among economists. However, effects of economic performance on political institutions have proven difficult to isolate. At the macro level, there are some studies identifying such effects (e.g. La Porta et al., 1999, and Chong and Calderón, 2000).

${ }^{9}$ Institutions have moved to the fore of mainstream explanations for economic performance, especially over the longer term; see, for example, North and Weingast (1989), Rodrik et al. (2004), and Acemoglu et al. (2005).
} 
institutions with economic significance, for example through their implications for voting systems, the degree of centralization and federalism (Persson and Tabellini, 2004, 2006).

We confine our analysis to formal institutions imposed through political decisions. Thus, we do not explicitly discuss informal rules such as norms, values and codes of conduct. ${ }^{10}$ Moreover, a formal institution that is not enforced is likely to lose its practical relevance. We will not elaborate further on the distinction between formal and enforced institutions. When referring to an institution we refer to its actual implementation and enforcement.

\subsection{Building Blocks}

We follow the general outline of the model proposed by Acemoglu et al. (2005). The structure of both economic and political institutions is determined by those with political power. There are two types of political power: de jure and de facto. De jure political power originates from political institutions, whereas de facto power stems from the possibility of wielding power without having to rely on political institutions. It is useful to think of de facto political power in terms of coups and upheavals. Although we consider less extreme instances, de facto power still requires the possession of resources. The significance of dividing political power into two distinct types is illustrated in Acemoglu and Robinson (2006), where negative effects on the elite's de jure political power, due to a reform, is offset by compensatory investments in de facto political power.

Economic outcomes are analyzed in two dimensions: economic performance and distribution. The first dimension refers to growth in resource stocks, national income and other common measures. The second covers the equality dimension, i.e., how resources are distributed in the population or among particular groups (e.g., ethnic, religious or gender) of the population. This distribution affects de facto political power. For instance, in a society with high inequality a wealthy minority is likely to wield a great deal of influence in the political sphere.

The model explicitly distinguishes between economic and political institutions. In terms of effect on economic outcome this implies a distinction between institutions that have a direct effect and those that have an indirect effect through the political process. The model also

\footnotetext{
${ }^{10}$ We also do not deal with factors such as social attitudes toward entrepreneurship as an individualistic venture (Hofstede, 2001). Schumpeter (1934) discussed how the entrepreneur broke away from old routines, so that special powers were required to endure social resistance caused by entrenched values.
} 
proposes an explicit link between economic outcome and political power. This effect emanates from the economic outcome in terms of distribution, which affects de facto aspects of political power directly. In addition, there is also an indirect effect; in a long-term perspective, de facto power will leave its mark on political institutions and thereby be translated into de jure political power.

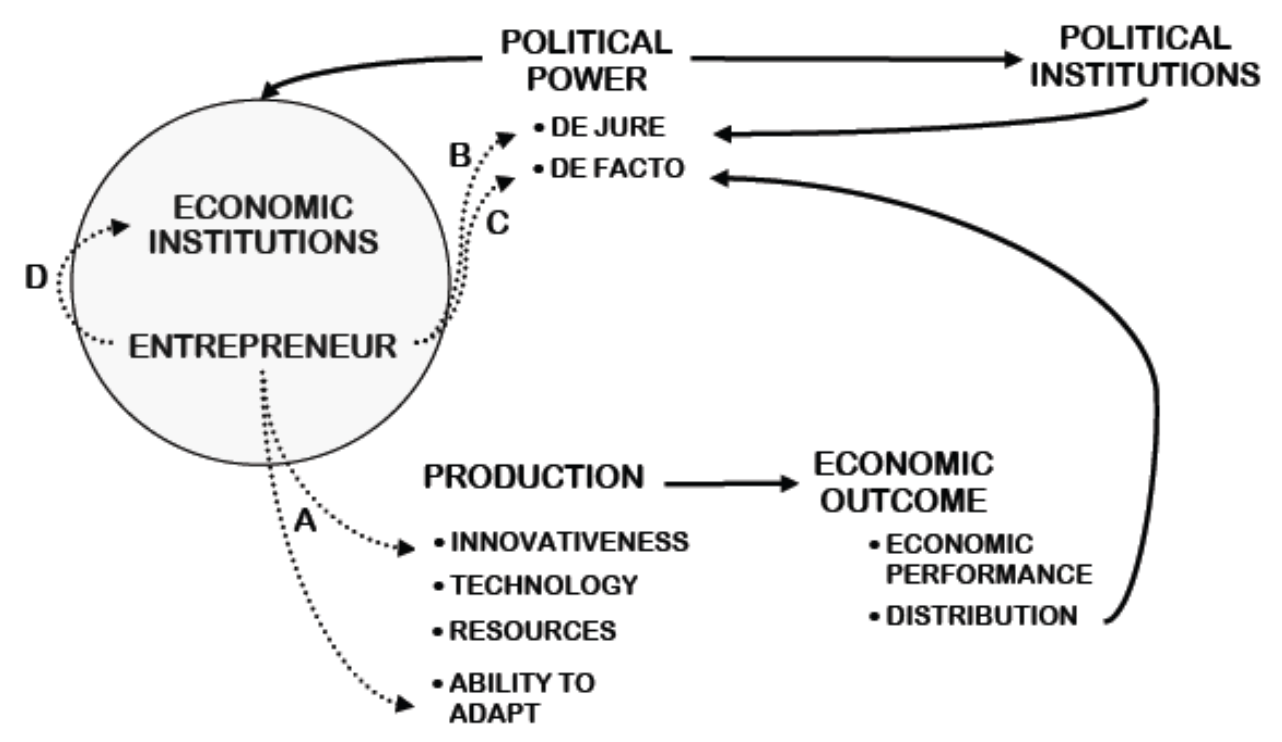

Figure 2. The Acemoglu et al. (2005) Growth System Supplemented with the Entrepreneur.

The mechanisms behind the link from economic institutions to economic outcome remain implicit in the Acemoglu et al. (2005) model. We close this gap by incorporating the entrepreneur and a production system, which is shown in Figure 2. It is essential to our approach that entrepreneurial activity can only be evaluated within a well-defined context. As a resource, the entrepreneur is qualitatively very different from capital and labor. The prevalence of productive and unproductive/destructive entrepreneurs is the joint outcome of institutions and entrepreneurial talent.

\subsection{Productive Entrepreneurship}

Productive entrepreneurship is illustrated by arrow A in Figure 2. The function of this type of entrepreneurship is to increase the innovativeness of an economy as well as its ability to adapt. Innovativeness refers to Schumpeter's (1934) entrepreneur who disturbs the existing 
equilibrium, while the ability to adapt captures the essence of Kirzner's (1973, 1992) entrepreneur. ${ }^{11}$

An economy's ability to adapt and renew itself through innovations is a key aspect of the production system. Productive entrepreneurship is the vehicle of these capacities. Capital (both human and physical) and labor are the inputs in a more or less productive environment, which allows for greater or less dynamism. In the limit, when no entrepreneurship of any form takes place, a static economy results.

Normally, productive entrepreneurship can be expected to enhance economic performance. Nevertheless, the relative need for adaptation and innovativeness is also likely to depend on the external environment. For instance, in times of rapid change, driven for example by a high rate of technological progress or new supplies of resources, adaptability becomes more important. $^{12}$

\subsection{Unproductive/Destructive Entrepreneurship I}

This type of entrepreneurship is illustrated by arrow B in Figure 2, running from the entrepreneur to de jure political power. Note here that we do not refer to the employment of entrepreneurial talent in politics per se (in contrast to, e.g., Holcombe, 2002). Instances of importance are when active business entrepreneurs directly enter a political body in order to wield de jure political power. The purpose of such interference is to bend the institutional framework to further their business interests.

Although recent governments of Italy (Silvio Berlusconi) and Thailand (Thaksin Shinawatra) give us some stark examples of this type of entrepreneurship, such activity appears to be exceptions rather than the rule in the developed parts of the world. One reason, in terms of Figure 2, is the increased separation between political and economic institutions. A despotic ruler or a small clique can only wield significant discretionary power when political institutions, political power and economic institutions are closely connected. Examples where this is more common include developing countries where the ruling elite benefits from

\footnotetext{
${ }^{11}$ See Baumol (2005), Holcombe (2007) and Yu (2001) for discussions of these two aspects and how they can be combined in the same system. See also Kirzner (2008) for a critical assessment of such merging.

${ }^{12}$ Our concept of adaptability is related to, and could be regarded as a subset of, North's (1990) "adaptive efficiency”. See also Myhrman (1989).
} 
inappropriate institutions and thus contributes to preserving the status quo irrespective of welfare costs (North, 1981; Lundahl, 1997). ${ }^{13}$

In a mature democracy, economic interests have a limited capacity to alter economic institutions directly. This is not to deny that political markets are present also in wellfunctioning democracies. Since Stigler (1971), it has been recognized that policy making is greatly influenced by lobbying and interest groups. Moreover, in the opposite direction, politicians may extract rents by threatening to impose unfavorable regulation (McChesney, 1987). This influence is captured by the next type of entrepreneurship.

\subsection{Unproductive/Destructive Entrepreneurship II}

Entrepreneurial talent can be used as part of the effort to wield de facto political power arrow $\mathbf{C}$ in Figure 2.

The most prevalent instance of this type of entrepreneurship is probably lobbying. Enormous resources are spent by companies in their lobbying efforts (Baumol, 2008). The prototypical case is where firms lobby to acquire certain monopoly rights. This type of entrepreneurship may be unproductive or destructive in two senses. First, in so far as most monopolies are man-made, convincing politicians to institute new monopoly rights amounts to a welfare loss (e.g., Murphy et al., 1993). Second, the resources spent by entrepreneurs in their lobbying efforts are often wasteful (Krueger, 1974). It is important to note that unproductive entrepreneurship in this sense often supplements productive effort and aims at increasing profit by obtaining some advantage relative to market competitors.

However, in so far as lobbying has become part of routine business conduct it does not qualify as entrepreneurship. For this to be the case we must require some innovative aspect. What arrow $\mathbf{C}$ partly intends to capture is how entrepreneurial talent is used as a complement to financial resources in an effort to wield de facto political power.

\footnotetext{
${ }^{13}$ In such contexts it is often difficult to implement requisite reforms, since the reforms themselves would undermine the political power of the ruling elite. One solution to this problem would be for the prospective winners of the reforms to make binding commitments to compensate the ruling elite. All parties could potentially benefit from such an arrangement. However, without a third party to guarantee compliance, binding commitments are difficult to enforce (Acemoglu et al., 2005).
} 


\subsection{Unproductive/Destructive Entrepreneurship III}

This type of unproductive entrepreneurship is illustrated by arrow $\mathbf{D}$ which feeds back into the institutional framework. In this case the activities of the entrepreneur do not alter the formal institutional setup but rather the effect of institutions that are already in place. Imperfections in the institutional setup can be used innovatively to appropriate rents from a third party.

The most salient example is shortcomings in the protection of private property rights. Agents may act on such institutional flaws by outright theft, fraud, litigation or more sophisticated economic crimes. The limitations in formal institutions protecting private property only carry a cost as long as agents take advantage of them - unproductive and destructive entrepreneurship of this type implies finding new ways to take advantage of institutions. Again we emphasize that many instances of the activities mentioned do not classify as entrepreneurship since they fail to be innovative.

Other examples are entrepreneurs who find contractual arrangements that escape some costly institution. Tax evasion is the prototypical example. A business-owning entrepreneur can engage in such evasive entrepreneurship to reduce costs. In some cases, notably tax consultancies and law firms, an entrepreneur can found a new business based on an innovation that circumvents costly institutional barriers.

Other, more mundane, instances of this type of activities include the businessman who uses his entrepreneurial talent to trace the right bureaucrat to approach with a bribe. In the simplest case this is an instance of evasive entrepreneurship. One can however think of more elaborate situations where the entrepreneur earns money by selling services utilizing knowledge of bureaucratic procedures or personal acquaintances. The bureaucrat who receives the bribe can also act entrepreneurially, for instance by increasing the cost of abiding by the institutions.

What all of these cases have in common is that they change the effect of formal institutions. This in turn will affect the profit earned by the same individual in the role of productive entrepreneur or the profit of other agents.

\subsection{Political Response}

In the first two cases of unproductive and destructive entrepreneurship discussed, the activities were directly aimed at triggering a political response to change certain features of 
the institutional setup. In the third kind discussed, the intention of the entrepreneur was not to change the formal institutions, but rather the effect of these institutions.

In a general equilibrium framework, politicians will respond to evasion and activities founded on institutional shortcomings by closing loopholes and amending institutions. But, it is important to note that politicians are not able to predict the behavior of entrepreneurs. When deciding on institutions rational politicians should obviously take the responses of entrepreneurs into account. However, due to the properties of entrepreneurs it is not possible for the politicians to apply a Ramsey-type decision rule where the profit-maximizing responses of agents are explicitly included. The political system has to be able to adapt and respond continually as new instances of unproductive entrepreneurship emerge.

Moreover, politicians' objectives may be influenced by the activities of unproductive entrepreneurs. We must specifically consider instances where entrepreneurs wield political power. Most importantly, an unproductive entrepreneur who uses some institutional shortcoming to appropriate rents has an incentive to see to it that the malfunctioning institutions are maintained.

Finally, there is an important cumulative aspect to entrepreneurship in so far as financial resources are needed in combination with entrepreneurial talent. Empirical evidence suggests that entrepreneurship is a powerful engine of social change and the formation of new economic elites (Holtz-Eakin et al., 2000, Quadrini, 1999, and Gentry and Hubbard, 2000).

\section{Historical Examples}

We now use examples from recent history to illustrate our model. After addressing the role of institutions in channeling entrepreneurs in different directions, we clarify the extent to which entrepreneurs are able to affect institutions, in particular by mustering de facto political power. The role of political institutions is also explored. With respect to the last two issues we acknowledge that the examples are sketchy. This is largely due to lack of previous research.

\subsection{The Allocation of Entrepreneurship}

China's transition to a Socialist command economy provides our first example. China is a particularly interesting case since entrepreneurs are also likely to be key agents in the more 
recent transition from Socialist planning (see 4.3). The move to a full-blown Socialist regime after the Communist revolution in 1949 was a gradual process completed in 1956-57. ${ }^{14}$ Stepby-step, private enterprise was circumscribed as more and more sectors were collectivized and government involvement in management was extended. In a first move from 1949 to 1952 private financial institutions were nationalized and private capital markets were shut down. The government began placing processing orders with private producers and took charge of large part of the allocation of resources. Plans for production and sales had to be approved by officials.

Entrepreneurs were still allowed to operate in the market and respond to market signals, but the institutional reforms brought about far-reaching changes in the way entrepreneurs operated. Entrepreneurial activity was reduced to a contest for processing orders and escaping controls. At the same time, the system offered ample opportunities for officials in charge of processing orders and means of production to earn rents through corruption. The consequences for private firms and the economy as a whole were highly detrimental. In 1951, the government began to strike at the "five evils": bribery of government officials, tax evasion, theft of state property, cheating on government contracts, and theft of economic information for speculative purposes. The blame was largely directed towards the private sector and resulted in an accelerated rate of collectivization and nationalization of resources.

The Communist takeover radically changed the institutional setup in China. The new institutions drastically increased the cost of productive entrepreneurship. Entrepreneurs were forced to expend an increasing amount of effort on evasive activities. The new institutions also provided fertile soil for unproductive forms of entrepreneurship. Rents could be earned by competing for bureaucratic positions that functioned as gatekeepers for licenses and government contracts. These changes legitimated demands for further institutional reforms. Radical Communist factions gained political power as private enterprise was blamed for the malfunctioning quasi-Socialist economy. The increased power of these groups induced further changes in economic institutions.

Another country where collectivist ideologies had an impact on many of the institutions is Sweden. In contrast to China, Sweden maintained strong democratic institutions and a high

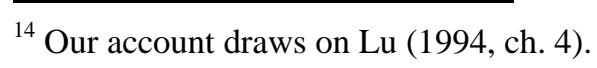


level of protection of private property rights throughout the twentieth century. Still, policies were implemented that consistently eroded the accumulation of private wealth, private ownership of the business sector and, ultimately, productive entrepreneurship. As shown by Henrekson and Jakobsson (2001), tax and industrial policies moved the economy towards larger business entities, institutional rather than individual ownership and high debt-equity ratios. Taxation at the firm level was low for large, capital-intensive and largely debt-financed firms, while it was high at the owners' level (in real terms often exceeding 100 percent for individual owners). This created a large wedge between wealth accumulation at the corporate and individual levels, thereby benefiting large incumbent firms relative to new entrants and individual entrepreneurs. ${ }^{15}$ The major incumbent owners managed to retain control despite this large wedge through a growing disparity between control rights and cash-flow rights. A number of devices were used to achieve this, the most important of which were dual-class shares and pyramiding with tax-favored closed-end investment funds as the prime control vehicle. It was not until the comprehensive tax reform in the early 1990s and the deregulation of credit markets that individual entrepreneurship and new-firm formation could gain in importance and challenge incumbent firms and capital owners.

The institutional framework in Sweden seems to have precluded many opportunities for productive entrepreneurship, and sharply increased the cost of other opportunities. This hampered productive entrepreneurship, whereas entrepreneurs clearly did not increase activities with directly harmful social consequences. It is probably fair to say that the long-run effects of Socialist institutions and ideology have had a stifling effect on the supply of entrepreneurial effort. However, the extent to which entrepreneurial effort was exerted in circumventing and manipulating regulation, i.e., evasive and unproductive entrepreneurship, should not be underestimated.

\subsection{Wielding de facto Political Power}

At a macro level of analysis, most examples of entrepreneurial influence hinges on the previous accumulation of wealth. In previous studies, the negative implications of wealth concentration are the most dramatic in models where business owners can form interest

\footnotetext{
${ }^{15}$ The actual effects of these policies on such variables as the size distribution of firms and employment and the industry distribution of production and employment are documented in Davis and Henrekson (1997).
} 
groups to persuade politicians to bar new entrants from the market (e.g., Do, 2004). ${ }^{16}$ But many accounts are less pessimistic. For instance, Baumol (2002) describes how strong economic interests historically managed to strike bargains with the ruling elite by inducing them to relinquish some of their discretion over property rights. This, in turn, created incentives for productive entrepreneurship and sparked a cumulative process where institutions that favored secure property rights gradually replaced existing institutions characterized by arbitrary seizure of property by the ruler and other arbitrary decisions. The cases presented here qualify the issue of wealth accumulation further. In relation to our model it should nevertheless be noted that this is only one of several possible ways by which entrepreneurs influence institutions.

According to Åslund, Boone and Johnson (2002) post-Soviet Russia is locked in an "underreform trap". The political dimension of this trap is evidenced by the continued political strength and influence of the former Communist elite. Moreover, political influence of large firms in Russia is often related to the oligarchs (Guriev and Rachinsky, 2005). This group consists of people from the former Soviet nomenclature who, after the fall of the Soviet Union, seized power over the companies that previously they only managed. A typical pattern in former Socialist countries is that former party cadres take advantage of their pre-reform position and their social network. ${ }^{17}$ Other Russian oligarchs are relatively young entrepreneurs who amassed their wealth in the late 1980s. They took advantage of the huge arbitrage opportunities created by partial reforms and the co-existence of regulated and quasimarket prices during the Gorbachev era. Today, the oligarchs' far-reaching influence on the economy and the opportunities for entrepreneurs in general have, among other things, resulted in the takeover of the Russian Union of Industrialists and Entrepreneurs. The prevalence of political influence of large firms at the local level, and the negative effect on entry of new firms is underscored by Slinko et al. (2005). ${ }^{18}$ Other research has shown that in comparison to

\footnotetext{
${ }^{16}$ Another possible mechanism that has been pursued in theoretical work is resistance to new innovations. Groups with vested interests try to influence economic institutions in order to prevent the introduction of new innovations (e.g., Mokyr, 1999). Since it is seldom costless to convert human and physical capital investment to suit new production technology some groups normally face (at least) a short-term loss in terms of unemployment or capital obsolescence. Such groups can potentially form a political alliance against change (Krusell and RíosRull, 1996). Other potential losers are incumbent firms with monopoly power (Parente and Prescott, 1999).

17 In a study from Hungary, using statistics on prior party position and post-reform engagement in entrepreneurship, Rona-Tas (1994) found that party cadres were more likely to own a non-corporate business, although the effect disappears when education is controlled for. However, the positive relationship between cadre membership and involvement in a corporate business is robust to the inclusion of education.

${ }^{18}$ Slinko et al. (2005) find that firms that were not subject to preferential treatment (primarily tax breaks and subsidized loans) experienced slower growth in regions with a high degree of political capture. Moreover, a high
} 
other more successful transition economies (e.g., Poland and Slovakia), Russian entrepreneurs face more corruption, higher official as well as unofficial start-up costs, higher tax rates, more bureaucracy, and weaker protection of property rights. These weak property rights have severely impeded the willingness of firms to reinvest their profits (Åslund et al., 2002).

What is of interest here is not primarily how currently weak protection of property rights shrinks the set of productive opportunities and how it instead breeds unproductive and destructive entrepreneurship. It is rather how a powerful elite seems to have a large impact on the institutions. This elite partly consists of entrepreneurs who, during the transition phase, could earn exceptionally large rents. This group now expends effort and resources in order to wield de facto political power.

Our next example deals with the Chinese minority in Indonesia. Although examples of Chinese influence can be found in many Southeast Asian countries, the Chinese dominance in Indonesia is striking. Chua (2004) describes how the historically strong position of Chinese entrepreneurs in Indonesia shaped its post-colonial history. Unlike Socialist-inspired takeover of private property in many other countries during this period, the wave of nationalizations during President Sukarno's rule in the 1950s and 1960s was motivated more by ethnic conflicts than by a desire to eradicate private ownership. Economically influential minorities, in particular the Chinese, were targeted. As a result of nationalizations, the Indonesian economy was fraught with widespread corruption and poorly managed enterprises. When Suharto seized power in 1966, he endorsed economic liberalization and foreign investments. In so doing, he allied himself with the Chinese business community - which had retained much of its economic influence - and with Chinese entrepreneurs. During Suharto's autocratic rule, the Chinese minority enjoyed protection. Large corporations were treated preferentially and endowed with lucrative business opportunities. This symbiosis also enabled the ruling family to accumulate a massive fortune. When the Suharto regime fell in 1998, the Sino-Indonesian minority (about 3 percent of the population) controlled approximately 70 percent of the private sector. The collapse of the Suharto regime was followed by antiChinese violence and resulted in the break-up of Chinese conglomerates and redistribution of their assets. Many formerly profitable companies subsequently experienced severe difficulties under their new management. 
In contrast to the Russian case, the wealthy Chinese minority in Indonesia has not been able to retain its political influence. During Suharto's regime the Chinese minority had a major influence on the institutions. To the extent that this influence barred native Indonesians from earning economic rents, it was in fact, plausibly, an important reason why the Suharto regime was overthrown. The indigenous majority managed to muster enough de facto political power to overthrow the regime. Although the Russian case spans a shorter time period than the Indonesian one, the contrast between them illustrates the importance of recognizing the importance of the distribution of wealth, in this case among ethnic groups.

\subsection{Other Types of Entrepreneurial Influence}

In our last example, we return once again to China. After the death of Mao in 1976, Deng Xiaoping rose to power in 1978 and initiated reforms that extended the scope of private enterprise. One example of the role of the entrepreneur in the ensuing transformation of Chinese institutions was the implementation of the practice of "contract-production-tohousehold”, which allocated land to households on a long-term basis and allowed farmers to retain the profits. This practice was officially endorsed in 1983, but had already been widely adopted. The former laws which prohibited private profits from household farming had lost all practical relevance. Another example is the policy document enforced in 1981, according to which limited private enterprise was allowed, but with severe restrictions on, for instance, the maximum number of employees (two employees and five apprentices). However, these limitations did little to confine the size of private firms, many of which grew well beyond the size permitted. By the end of 1986, an official survey showed that a large number of firms had exceeded the stipulated limits. New institutional reforms in 1987-88 then granted these firms legitimate status. Lu (1994, p. 117) concludes that "the Chinese policy makers did not predesign the boom of the private sector in the 1980s and the relating changes in institutions. In many cases, what happened was the official adaptation to reforms initiated by private entrepreneurs."

Daokui et al. (2006) use the term "institutional entrepreneur" for someone who starts a business venture and thereby contributes to the destruction of prevailing institutions that are unfavorable to entrepreneurship. Apart from open advocacy of reforms and private persuasion of politicians, they mention two other strategies. A business owner can claim that he represents a special case and that exceptions should be made for him. Once a concession has 
been made, additional concessions are easier to obtain, and numerous exceptions amount to a de facto change in institutions. The other strategy is to begin by circumventing regulations and, once a successful enterprise has been established, argue for an ex post modification. ${ }^{19}$ As observed by Gilley (2002), Chinese politicians appointed at the local level frequently have a background as former (or current) entrepreneurs. Furthermore, Djankov et al. (2006) present evidence that Chinese entrepreneurs value political freedom significantly more than nonentrepreneurs. These results suggest that entrepreneurs might be an important force also in bringing about change in political institutions.

Although many of the Chinese institutions that imposed restrictions on entrepreneurship were still in place in the mid-1970s, the political will to enforce such restrictions weakened under Deng Xiaoping. The risk of sanctions, and hence the cost of evading the institutions in question, decreased significantly. We have seen how this enhanced productive entrepreneurial activity. This was a cumulative process by which the costs of evading regulation fell to a level where the constraints of institutions had lost all practical relevance, and in the end they were formally abolished.

\section{Discussion}

The distinction between unproductive and destructive entrepreneurship has been made in terms of the effect on the production possibility frontier. In practice the separation is difficult to make, and has played little role in the discussion so far. Moreover, although it seems to be of some practical relevance to separate between activities that impose more or less cost on overall production, we believe that the distinction can be questioned on theoretical grounds.

The reason is that in the framework proposed, entrepreneurial talent is viewed as a resource, and hence it is subject to scarcity of supply. Thus, even if entrepreneurial talent is channeled to unproductive activities that merely entail a redistribution of resources this implies an opportunity cost in terms of foregone productive potential. Hence, the production possibility frontier is closer to the origin compared to the case when the talent is put to productive use.

\footnotetext{
${ }^{19}$ These kinds of "institutional entrepreneurship" have, according to the authors, changed the institutional environment in rapidly growing economies such as China, India and Vietnam.
} 
Another, more complex, issue is whether the activities labeled unproductive entrepreneurship are necessarily welfare reducing. A case in point is the tax consultant who helps other productive entrepreneurs to evade costly taxes. If the tax structure is suboptimal, such an activity could imply an increase in aggregate output; the enhanced performance of productive entrepreneurs may well counterbalance the direct costs and opportunity costs from a suboptimal allocation of entrepreneurial talent. In other words, unproductive entrepreneurship may in other words provide a second-best remedy for poorly functioning institutions.

The same case can be made in more extreme instances. Take, for example, the Mafia which is by many accounts the prototypical form of unproductive or even destructive entrepreneurship. However, as several authors have argued, the Mafia can under some circumstances substitute for lacking public institutions (Bandiera, 2003; Milhaupt and West, 2000; Dixit, 2004). Given severe shortcomings of institutions to protect private property rights, the Mafia may provide some stability for productive entrepreneurs, and therefore increase aggregate output.

\section{Conclusion}

This paper introduces a framework that relates entrepreneurship and politically determined institutions by unifying contributions from research in the areas of entrepreneurship/small business, public choice and the political economy of economic growth. Entrepreneurs are characterized by an aptitude for recognizing and exploiting economic opportunities. The political economy aspect is brought in by recognizing that these opportunities may be found outside the production system narrowly defined.

A political economy framework allows for bilateral causal relationships between entrepreneurship and institutions. On the one hand, entrepreneurs choose how and to what extent they want to employ their entrepreneurial talent depending on the relevant incentive structure as determined by the pertinent institutions. In this way, institutions fundamentally determine the distribution across productive, unproductive and destructive entrepreneurial activities. Moreover, given restrictive institutions entrepreneurs may find it economically rational to expend some effort on evading these institutions.

On the other hand, it is inherent to our definition of entrepreneurs that they respond actively to the environment they face. Some of these responses are likely to affect the politically 
determined institutions. We isolate three main types of such response. First, entrepreneurs may engage directly in politics; by wielding de jure political power, they further the interests of their businesses. Second, entrepreneurial talent is an important complement to other resources in the effort to wield de facto political power, primarily through lobbying. The third instance involves not changes to formal institutions but to how institutions are implemented in practice. For instance, shortcomings in the protection of property rights can be exploited to appropriate rents from others and innovative contractual forms can be used to reduce the cost of institutional barriers.

Since these types of activities all involve a measure of innovation, politicians cannot fully account for these effects when designing institutions. This is important from a policy perspective. Institutional changes aimed at promoting entrepreneurship must always be evaluated with respect to what kind of entrepreneurship is promoted. A tax hike may not only deter productive entrepreneurs, but also foster unproductive/destructive entrepreneurship. Merely examining the net effect on entrepreneurial activity in general is likely to be highly misleading.

More generally, the analysis highlights the need to view the formation of institutions as an adaptive process. Politicians cannot design optimal institutions once and for all. Unpredictable entrepreneurial responses to these institutions will force politicians to respond by continually changing and amending the institutional environment.

Research on the political economy of entrepreneurship cannot be restricted to analyzing how institutions affect the level and type of entrepreneurial activity. It is also necessary to consider how entrepreneurial activities affect institutions and thereby the prospects for long-term growth. Our real-world examples provide some intuition for such an analysis. 


\section{References}

Acemoglu, Daron (1995), "Reward Structures and the Allocation of Talent”, European Economic Review, 39(1), 17-33.

Acemoglu, Daron and James A. Robinson (2006), “Persistence of Power, Elites and Institutions”, American Economic Review, 98(1), 267-293.

Acemoglu, Daron, Simon Johnson and James A. Robinson (2005), "Institutions as the Fundamental Cause of Long-run Growth”, in Philippe Aghion, and Steven Durlauf (eds.), Handbook of Economic Growth, Amsterdam: North-Holland.

Åslund, Anders, Peter Bonne and Simon Johnson (2002), “Escaping the Under-Reform Trap”, IMF Staff Papers $48,88-108$.

Bandiera, Oriana (2003), "Land Reform, the Market for Protection, and the Origins of the Sicilian Mafia: Theory and Evidence", Journal of Law, Economics and Organization, 19(1), 218-244.

Baumol, William J. (1990), “Entrepreneurship: Productive, Unproductive, and Destructive”, Journal of Political Economy, 98(5), 893-921.

Baumol, William J. (2002), The Free-Market Innovation Machine, Princeton University Press: Princeton and Oxford.

Baumol, William J. (2005), “Entrepreneurship and Invention: Toward Restoration into Microeconomic Value Theory”, mimeo, Berkley Center for Entrepreneurial Studies, New York University.

Baumol, William J. (2008), “Mega Entrepreneurs: Active Molders and Creators of Key Institutions”, mimeo, Berkley Center for Entrepreneurial Studies, New York University.

Boettke, Peter J. and Christopher J. Coyne (2003), "Entrepreneurship and Development: Cause or Consequence?”, Advances in Austrian Economics, 6, 67-87.

Buchanan, James M. (1980), "Rent Seeking and Profit Seeking,” in James M. Buchanan, and Gordon Tollison (eds.), Toward a Theory of the Rent-Seeking Society, College Station, TX: Texas A\&M University Press.

Chong, Alberto and César Calderón (2000), "Causality and Feedback between Institutional Measures and Economic Growth”, Economics and Politics, 12(1), 69-82.

Chua, Amy (2004), World on Fire, London: Arrow Books.

Coyne, Christopher J. and Peter T. Leeson, (2004), “The Plight of Underdeveloped Countries”, Cato Journal, 24(3), 235-249.

Daokui Li, David, Junxin Feng and Hongping Jiang (2006), “Institutional Entrepreneurs”, American Economic Review, 96(2), 358-362.

Davis, Steven J. and Magnus Henrekson (1997), ’Industrial Policy, Employer Size and Economic Performance in Sweden”, in Richard B. Freeman, Robert Topel and Birgitta Swedenborg (eds.), The Welfare State in Transition, pp. 353-397, Chicago: University of Chicago Press.

Dixit, Avinash K. (2004), Lawlessness and Economics, Princeton, NJ: Princeton University Press.

Djankov, Simeon, Yingyi Qian, Gérard Roland and Ekaterina Zhuravskaya (2006), "Entrepreneurship in China and Russia Compared", Journal of European Economic Association, 4(2/3), 352-365.

Do, Quy Toan (2004), “Institutional Trap”, World Bank Policy Research Working Paper No. 3291, Washington, DC.

Gaglio, Connie Marie and Jerome A. Katz (2001), "The Psychological Basis of Opportunity Identification: Entrepreneurial Alertness”, Small Business Economics, 16(2), 95-111.

Gartner, William B. (1990), “What Are We Talking about when We Talk about Entrepreneurship?”, Journal of Business Venturing, 5(1), 15-28.

Gartner, William B. (2001), "Is There an Elephant in Entrepreneurship? Blind Assumptions in Theory Development”, Entrepreneurship Theory and Practice, 25(1), 27-39.

Gentry, William M. and R. Glenn Hubbard (2000), “Entrepreneurship and Household Saving”, NBER Working Paper No. 7894.

Gilley, Bruce (2002), "Entrepreneurs and Politics in Rural China”, in Victoria E. Bonnell, and Thomas B. Gold (eds.), The New Entrepreneurs of Europe and Asia, New York and London: M.E. Sharpe.

Guriev, Sergei and Andrei Rachinsky (2005), “The Role of Oligarchs in Russian Capitalism”, Journal of Economic Perspectives, 19(1), 131-150.

Hall, Robert E. and Charles I. Jones (1999), "Why Do Some Countries Produce So Much More Output Per Worker than Others?”, Quarterly Journal of Economics, 114(1), 83-116. 
Hébert, Robert F. and Albert N. Link (2006), “Historical Perspectives on the Entrepreneur”, Foundations and Trends in Entrepreneurship, 2(4), 261-408.

Henrekson, Magnus and Ulf Jakobsson (2001), "Where Schumpeter Was nearly Right - the Swedish Model and Capitalism, Socialism and Democracy”, Journal of Evolutionary Economics, 11(3), 331-358.

Hofstede, Geert (2001), Culture’s Consequences ( $2^{\text {nd }}$ ed), Thousand Oaks, CA: Sage Publications.

Holcombe, Randall G. (2002), "Political Entrepreneurship and the Democratic Allocation of Resources”, Review of Austrian Economics, 15(2/3), 143-159.

Holcombe, Randall G. (2007), Entrepreneurship and Economic Progress, New York: Routledge.

Holtz-Eakin Douglas, Harvey S. Rosen and Robert Weathers (2000), "Horatio Alger Meets the Mobility Tables”, Small Business Economics, 14(4), 243-274.

Kirzner, Israel M. (1973), Competition and Entrepreneurship, Chicago and London: University of Chicago Press.

Kirzner, Israel M. (1992), The Meaning of the Market Process - Essays in the Development of Modern Austrian Economics. Routledge: New York.

Kirzner, Israel M. (2008), “The Alert and Creative Entrepreneur: A Clarification”, Small Business Economics, forthcoming.

Knight, Frank H. (1921), Risk, Uncertainty and Profit, New York: Houghton Mifflin.

Krueger, Anne O. (1974), “The Political Economy of the Rent-Seeking Society”, American Economic Review, 64(3), 291-303.

Krusell, Per and José-Víctor Ríos-Rull (1996), “Vested Interests in a Theory of Stagnation and Growth”, Review of Economic Studies, 63(2), 301-329.

La Porta, Rafael, Florencio Lopez-de-Silanes, Andrei Shleifer and Robert Vishny (1999), “The Quality of Government”, Journal of Law, Economics and Organizations, 15(1), 222-279.

Lu, Ching (1994), Entrepreneurship in Suppressed Markets: Private-Sector Experience in China, New York: Garland.

Lundahl, Mats (1997), "Inside the Predatory State. The Rationale, Methods, and Economic Consequences of Kleptocratic Regimes”, Nordic Journal of Political Economy, 24(1), 31-50.

McChesney, Fred S. (1987), "Rent Extraction and Rent Creation in the Economic Theory of Regulation”, Journal of Legal Studies, 16(1), 101-118.

McClelland, David C. (1961), The Achieving Society, Princeton: Van Nostrand.

Milhaupt, Curtis J. and Mark D. West (2000), “The Dark Side of Private Ordering: An Institutional and Empirical Analysis of Organized Crime”, University of Chicago Law Review, 67(1), 41-98.

Mokyr, Joel (1999), “Innovation and Its Enemies: The Economic and Political Roots of Technological Inertia”, in Mancur Olson and Satu Kähkönen (eds.), A not so Dismal Science, Oxford: Oxford University Press.

Murphy, Kevin M., Andrei Shleifer and Robert W. Vishny (1991), “The Allocation of Talent: Implication for Growth”, Quarterly Journal of Economics, 106(2), 503-530.

Murphy, Kevin M., Andrei Shleifer and Robert W. Vishny (1993), "Why is Rent Seeking so Costly to Growth?”, American Economic Review, 83(2), 409-414.

Myhrman, Johan (1989), “The New Institutional Economics and the Process of Economic Development”, Journal of Institutional and Theoretical Economics, 145(1), 38-59.

North, Douglass C. (1981), Structure and Change in Economic History, New York and London: Norton.

North, Douglass C. (1990), Institutions, Institutional Change and Economic Performance, Cambridge: Cambridge University Press.

North, Douglass C. and Barry R. Weingast (1989), "Constitutions and Commitment: Evolution of Institutions Governing Public Choice in Seventeenth Century England”, Journal of Economic History, 49(4), 803-832.

Parker, Simon C. (2004), The Economics of Self-Employment and Entrepreneurship, Cambridge: Cambridge University Press.

Parente Stephen L. and Edward C. Prescott (1999), “Monopoly Rights as Barriers to Riches”, American Economic Review, 89(5), 1216-1233.

Persson, Torsten and Guido Tabellini (2004), “Constitutions and Economic Policy”, Journal of Economic Perspectives, 18(1), 75-98.

Persson, Torsten and Guido Tabellini (2006), “Electoral Systems and Economic Policy”, in Barry R. Weingast and Donald A. Wittman (eds.), Handbook of Political Economy, New York: Oxford University Press.

Quadrini, Vincenzo (1999), “The Importance of Entrepreneurship for Wealth Concentration and Mobility”, Review of Income and Wealth, 45(1), 1-40. 
Rauch, Andreas and Michael Frese (2000), "Psychological Approaches to Entrepreneurial Success. A General Model and an Overview of Findings”, in Cary L. Cooper and Ivan T. Robertson (eds.), International Review of Industrial and Organizational Psychology, Chichester: Wiley, 101-142.

Rodrik, Dani, Arvind Subramanian and Francesco Trebbi (2004), “Institutions Rule: The Primacy of Institutions over Geography and Integration in Economic Development”, Journal of Economic Growth, 9(2), 131-165.

Rona-Tas, Akos (1994), “The First Shall Be Last? Entrepreneurship and Communist Cadres in the Transition from Socialism”, American Journal of Sociology, 100(1), 40-69.

Schumpeter, Joseph A. (1934), The Theory of Economic Development, Cambridge, MA: Harvard University Press.

Slinko, Irina, Evgeny Yakovlev and Ekaterina Zhuravskaya (2005), "Law for Sale: Evidence from Russia”, American Law and Economics Review, 7(1), 284-318.

Sobel, Russell S. (2008), “Testing Baumol: Institutional Quality and the Productivity of Entrepreneurship”, Journal of Business Venturing, forthcoming.

Stigler, George J. (1971), “The Theory of Economic Regulation”, Bell Journal of Economics and Management Science, 2(1), 3-21.

Ward, Thomas B. (2004), “Cognition, Creativity and Entrepreneurship”, Journal of Business Venturing, 19(2), 173-188.

Weber, Max (2001 [1905]), The Protestant Ethic and the Spirit of Capitalism, London and New York: Routledge.

Wennekers, Sander and Roy Thurik, (1999), “Linking Entrepreneurship and Economic Growth”, Small Business Economics, 13(1), 27-56

Yu, Tony Fu-Lai (2001), “An Entrepreneurial Perspective of Institutional Change”, Constitutional Political Economy, 12(3), 217-236. 